Bush E Grotjohann, 2018

Volume 2 Issue 2, pp.189-203

Date of Publication: 17th September 2018

DOI-https://dx.doi.org/10.20319/pijtel.2018.22.189203

This paper can be cited as: Bush, A., Grotjohann, N. (2018). Professionalization through Collaboration in Teacher Education - Identifying the Status Quo. PUPIL: International Journal of Teaching, Education and Learning, 2(2), 189-203.

This work is licensed under the Creative Commons Attribution-NonCommercial 4.0 International License. To view a copy of this license, visit http://creativecommons.org/licenses/by-nc/4.0/ or send a letter to Creative Commons, PO Box 1866, Mountain View, CA 94042, USA.

\title{
PROFESSIONALIZATION THROUGH COLLABORATION IN TEACHER EDUCATION - IDENTIFYING THE STATUS QUO
}

\author{
Annika Bush \\ Research assistant, Faculty of Biology, Department of Science Education, Bielefeld University, \\ Bielefeld, Germany \\ annika.bush@uni-bielefeld.de \\ Norbert Grotjohann \\ Professor of Science Education, Faculty of Biology, Bielefeld University, Bielefeld, Germany \\ norbert.grotjohann@uni-bielefeld.de
}

\begin{abstract}
Teacher collaboration together with (self-)reflection is a key factor to improve teacher professionalism. Nevertheless, collaboration among teachers is not being used sufficiently. One approach to change this is to implement collaborative behaviours earlier, in the university-based teacher-training. To develop eligible methods, the status quo must be defined first. Therefore, this paper researches how, with whom and why education students and trainee teachers collaborate. The study is based on a mixed methods design: At first, qualitative interviews were held to define the structures of collaboration. Main results were, that especially students in the examined internship prefer to collaborate with teachers rather than with their fellow students. Also, collaboration happens spontaneously, and planned structures between teachers and interns are rarely found. All in all, the main collaboration form is exchange (of materials and information) whereas higher forms of collaboration are seldomly realized. To gain more profound numbers, the results were transformed into a standardized questionnaire. In this
\end{abstract}


second quantitative study, 1763 educational science students and trainee teachers participated. The statistic results will be the base for a third study which will be qualitative again in form of episodic interviews. The aim is to explain the quantitative results and point out structures, where universities and schools can start to act and improve the teacher collaboration at an early point of their career to improve teacher professionalization through teacher education. This paper presents the results of the first two studies as well as the leading questions for the future interviews.

\section{Keywords}

Collaboration, Professionalization, Teacher Education, Mixed Methods

\section{Introduction}

Teamwork, collaboration, cooperation: These expressions evolved to key words within the last decades. Since the 1970s the topic is being transferred to the schooling sector and educational research. In fact, most of the research in this field accredits collaboration to support many positive outcomes such as a better school quality (Goddard, Goddard, \& TschannenMoran, 2007; Ronfeld, Matthew, Owens Farmer, McQueen, \& Grissom, 2015), healthier teachers (Schaarschmidt, 2005) and - for this study the most important finding - a profound, positive impact on teacher professionalization (Avalos, 2011; Vangrieken, Dochy, Raes, \& Kyndt, 2015).

Considering these scientific conclusions and many attempts to change collaborative behaviour in school, it astonishes that it still is not being performed naturally by teachers in most schools. The approach followed for this study is to implement collaborative behaviours already in teacher training in order to change the habitus in the school in general later on.

This study focusses on the German teacher education system in which the students must decide from the very beginning of their academic studies whether they want to study for becoming a teacher. With the obligatory subject of educational sciences, the undergraduate as well as the consecutive postgraduate programmes include a pre-service teacher training. After their academic studies, the students must complete a trainee teacher programme in school which takes 1,5 years before being fully trained teachers.

Within the past years, many German universities started to implement a six-month school internship in the master's programme. This is mandatory for all educational science students. As this internship is an innovative approach to optimize teacher education in Germany, it is also a 
chance to enhance co-operational behaviour. It is important to understand the current situation, before additional approaches are implemented to improve the new practical semester.

\section{Theoretical Framework}

\subsection{Collaboration in school context}

The concept of cooperation has a strong normative reference in school research: Teacher collaboration has been credited with positive results for decades. The benefits are associated with effectiveness and improvement in every school and classroom setting. Moreover, autonomous forms of teacher action are being discredited and research literature proposes the salvation through collaborative forms (Bondorf, 2013, p. 14) Collaboration is described as a guarantor of a better school (Bauer, 2008, p. 839). Most of these findings come from school effectiveness research, which shows that successful colleges have a high degree of collegial cooperation (Rothland, 2012, p. 191).

Since collaboration is almost always connoted positively, it is surprising that it is not being performed accordingly. Teachers rate collaboration high but do not act likewise. This has been confirmed by various studies since 1970, and so far it does not seem to change soon (Pröbstel \& Soltau, 2012; Rothland, 2012; Steinert et al., 2006; Werner, 2012). Weaknesses of the previous researches are that the collaboration between teachers is operationalized differently and there is still no consistent theoretical foundation and empirical coverage of the construct of cooperation between teachers (Bondorf, 2013, p. 14). In addition, the dominant method of detection has been limited to self-information of teachers so far (Bondorf, 2013, p. 14).

In 1990, Little developed a model for categorizing types of cooperation (Little, 1990). This has been advanced by Gräsel, Fußangel and Pröbstel in 2006 and their model continues to serve as the basis to categorize teacher collaboration in many studies in the German-speaking world (Gräsel, Fußangel, \& Pröbstel, 2006; Kuper \& Kapelle, 2012; Pröbstel \& Soltau, 2012; Richter \& Pant, 2016). The following study is also based on this model.

Gräsel et al. (2006) found the problem of the definition of terms in their own research: Many teachers see only the exchange of information or materials as a form of collaboration. In the model, this is classified as the lowest level of collaboration. Other forms such as team teaching, which are assigned to the field of co-construction and thus the most complex form of cooperation, are often either unknown or not perceived as collaboration in the classical sense. The middle level is described as division of labour (Gräsel et al., 2006, pp. 214-217). 
Several studies confirmed the findings of Gräsel et al. and found that exchange is the most performed kind of collaboration among teachers (Richter \& Pant, 2016; Steinert et al., 2006). The second most common collaboration form is division of labour. Co-construction is in third place and is performed relatively rarely (Gräsel et al., 2006; Richter \& Pant, 2016). They concluded, that the more complex the form of collaboration, the less it is performed (Gräsel et al., 2006; Steinert et al., 2006). Several researchers found out that the higher the educational level of the school was, the lower was the degree of collaboration among teachers (Bauer, 2008, p. 850; Steinert et al., 2006)

Investigations with teachers as well as education students showed, that both groups rated collaboration high but did not have the intention to perform it themselves (Rothland, 2012; Soltau). This shows that there is a gap between attitude towards collaboration and its implementation.

\subsection{Professionalization and collaboration in teacher education}

Many studies investigate their countries' teacher education system to find out weak spots and implement new structures to improve the teaching system (Cherechi, 2018; Meddour, 2017). Other studies state that a vocationalisation of university education might have a positive outcome on the students' work skills and competences (Houston, Krüger, Molas, Osborne, \& Jiménez, 2016). This study also believes that an early intervention can have an impact on the outcome of the future teachers' behaviour and therefore investigates the university level of teacher training.

Nowadays, collaboration is viewed as a factor not only for school improvement, but also for professionalization in teacher education (Bondorf, 2013, p. 29; Schüssler, Schwier, Klewin, Gabriele, Schicht, Saskia, Schöning, \& Weyland, 2014). The aim of the academic teacher education is that the students develop the ability to communicate about teaching-related content and problems as well as pedagogical-didactic issues. The traineeship is about testing and developing the trainee's own professional capacity. Collaboration should be performed to develop their teaching abilities and enhance the reflection of their actions (Terhart, 2002, p. 30).

Caused by the introduction of the practical semester, the boundaries between the theoretical and practical training were shifted. After several short internships during the student's bachelor studies, the students gain an extended insight into the teaching profession during the longer internship in their master studies. They now start earlier to train their own professional teacher personality. Therefore, the practical semester should not primarily focus on the practical action, but rather challenge the students to improve their self-reflection abilities and encourage 
them to work together with fellows and experts in favour of their professionalization (Schüssler et al., 2014, pp. 34-35).

Gräsel and Gruber (2000) also proclaim the enhancement of collaboration in early teacher education. They state that the capacity of teachers for collaboration is a central part of competent teacher action, which must be acquired, practiced and applied during the teacher training. It is demanded to apply cooperative structures already during the studies to ensure that the students successfully use the learned methods in their professional life in the future. However, not much of an implementation of this claim is yet to be seen (Gräsel \& Gruber, 2000, p. 173). It seems inevitable to pay more attention to this aspect. The practical semester can be an opportunity to influence student's collaborative behaviour. To implement a long-lasting collaboration system already during the teacher education, the status quo must be defined first.

\section{Study on the status quo}

To define the status quo of the collaboration in teacher education, an exploratory sequential design has been chosen. In the pre-study, interviews were held with students that finished the new practical semester. The results then served to develop a questionnaire based on Soltau which was filled out by 1763 students and trainee teachers.

The leading question is: how and with whom do prospective teachers collaborate? Furthermore, every study within the mixed methods design has its own sub-questions. These will be presented in the chapters below.

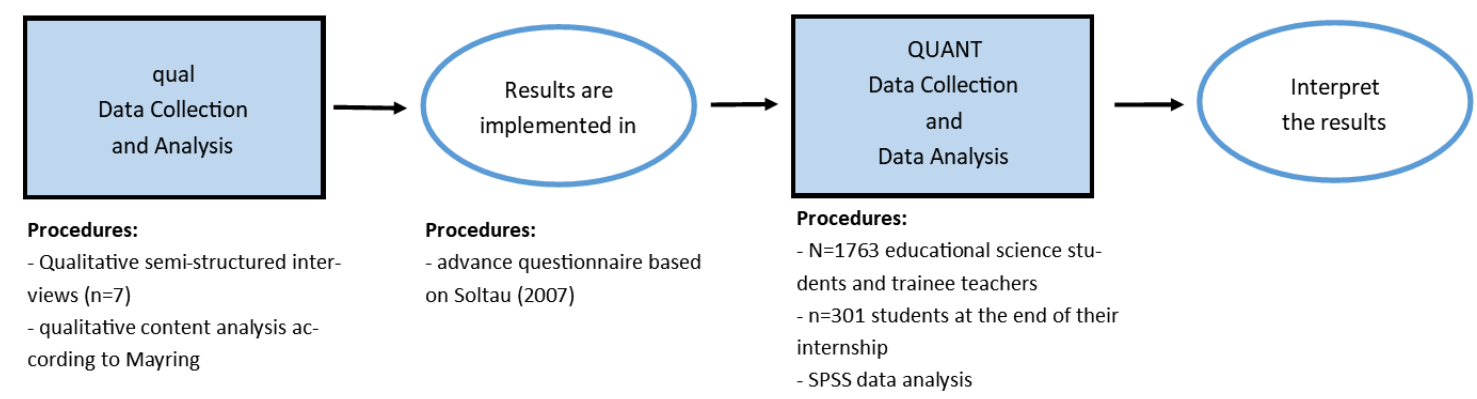

Figure 1: Mixed methods design with procedure description

\subsection{Qualitative study}

The first study served as a pre-study in which interviews were held with seven students who finished the practical semester in their master studies. The leading questions were whether, 
how and with whom students collaborated during their internship. The qualitative approach aimed to find out central aspects and special terms, that were relevant to the students. These were important to design a suitable questionnaire for the following quantitative study.

The results showed that the students collaborated on a basic level, as they mostly exchange information and sometimes material. Collaboration as in forms of division of work or co-construction were rarely conducted. Also, findings revealed that there was almost no collaboration with fellow students but mostly with designated mentor teachers and - depending on the individual internship structure given by the school - with other teachers allocated to the school.

The results were implemented in the questionnaire for the following quantitative study.

\subsection{Quantitative Study}

The quantitative study examined, how the students rate collaborative actions, whether they intended to perform them in the future and how they practiced them in their practical phases.

\subsection{Participants and procedure}

The sample size of the second study is $\mathrm{N}=1763$. These can be divided into four cohorts:

1. Educational science students at the beginning of their bachelor studies (first and second semester; $n=843$ ),

2. Educational science students in their master studies before the 6-month internship $(n=305)$,

3. Educational science students in their master studies at the end of the internship $(n=302)$ and

4. trainee teachers $(n=313)$.

The third cohort and the previous study both target students at the end or right after the internship. Therefore, the following descriptions and results focus on the third cohort.

\subsection{Instrument and data collection}

For the quantitative study, a closed questionnaire for teachers (Soltau) was adapted to include the results of the previous study as well as to fit to the situation of the respondents. Nine different, cooperative actions, which (can) occur in school, were described. The interviewees were asked to grade the action on a Semantical Differential rating scale. Afterwards they stated their intention of conducting the action in future. At last they filled out a matrix on how often they acted as described during their internship. Based on the first study, answers were 
differentiated between the collaboration with (1) fellow students, (2) designated mentors and (3) other trained teachers at their internship school.

The students were questioned in education seminars and lectures at the Bielefeld University with paper-pencil questionnaires. Trainee teachers from the state of North RhineWestphalia in Germany answered the same questions online. The data collection ran from May 2017 until April 2018.

\subsection{Hypotheses}

Four main hypotheses were derived from literature review and the previous interview study:

1. Primary school interns rate, intend and perform collaboration higher/more often than secondary school interns.

2. There is a gap between the rating, intention and performance of collaboration.

3. The students perform mainly exchange as collaboration form.

4. The more students collaborate with one group of partners (e.g. mentors), the less they collaborate with the other two groups (e.g. fellow students and other teachers).

\subsection{Findings and outcomes}

\subsubsection{Differences between primary and secondary teachers}

An independent-samples t-test was conducted to compare educational students that undertook their internships in primary and secondary school in rating, intention and performance of collaboration.

Regarding the rating, there was no significant difference in the scores of the students for primary school and secondary school conditions. However, there was a significant difference in the scores for intention. Students for a primary school teaching degree had a higher intention to execute collaborative actions than future secondary school teachers. As no significant differences in the performance of both groups were found, the intentions did not lead to a significantly different behaviour.

Therefore, the hypothesis can only be confirmed partly in case of intention. In rating and performance, there are no significant differences between the two groups.

Table 1: Mean value differences between primary and secondary school interns

\begin{tabular}{|l|l|l|l|l|l|l|l|}
\hline Level & $\begin{array}{l}\text { internship } \\
\text { school }\end{array}$ & $\mathbf{n}$ & $\mathbf{M}$ & SD & $\mathbf{t}$ & df & $\mathbf{p}$ \\
\hline Rating & primary & 144 & 5.11 & 0.43 & 1.435 & 292 & .152 \\
\hline
\end{tabular}




\begin{tabular}{|c|c|c|c|c|c|c|c|}
\hline & \multicolumn{4}{|l|}{ school } & & & \\
\hline & $\begin{array}{l}\text { secondary } \\
\text { school }\end{array}$ & 150 & 5.04 & 0.43 & & & \\
\hline \multirow{2}{*}{ Intention } & $\begin{array}{l}\text { primary } \\
\text { school }\end{array}$ & 145 & 3.94 & 0.4 & \multirow{2}{*}{3.952} & \multirow{2}{*}{295} & \multirow{2}{*}{.000} \\
\hline & $\begin{array}{l}\text { secondary } \\
\text { school }\end{array}$ & 152 & 3.76 & 0.38 & & & \\
\hline \multirow{2}{*}{ Performance } & $\begin{array}{l}\text { primary } \\
\text { school }\end{array}$ & 144 & 2.63 & 0.69 & \multirow{2}{*}{0.502} & \multirow{2}{*}{294} & \multirow{2}{*}{.616} \\
\hline & $\begin{array}{l}\text { secondary } \\
\text { school }\end{array}$ & 152 & 2.6 & 0.6 & & & \\
\hline
\end{tabular}

\subsubsection{Differences between rating, intention and performance}

A Pearson product-moment correlations coefficient was computed to assess the relationship between the rating, intention and performance of collaboration.

There was a significant correlation between the two variables of rating and intention. Positive rating of the actions was correlated with a high intention. A second, significant correlation can be found between the two variables of intention and performance. A high intention of acting correlated with the performance of the actions. There was no correlation between the two variables of rating and performance.

As the hypothesis proposes a gap between all three items, but a correlation of rating and intention as well as intention and performance were found, the hypothesis cannot be fully confirmed.

Table 2: Correlations between rating, intention and performance of collaboration

\begin{tabular}{|c|c|c|c|}
\hline & & Rating & Intention \\
\hline \multirow{3}{*}{ Rating } & Pearson corr. & & .635 \\
\hline & $p$ & & 0.000 \\
\hline & $n$ & & 299 \\
\hline \multirow{3}{*}{ Performance } & Pearson corr. & .083 & .245 \\
\hline & $p$ & 0.151 & 0.000 \\
\hline & $n$ & 298 & 301 \\
\hline
\end{tabular}




\subsubsection{Collaboration form}

To identify how often students undertook collaboration actions, a 5-point Likert scale was used. The scale values ranged from 'never' (1) over 'less than once a month' (2), 'one to two times per month' (3) and 'one to two times per week' (4) to 'several times a week' (5).

The nine different collaboration acts can be divided into three acts of exchange, three acts of division of work and three acts of co-construction.

As the hypothesis assumes, exchange is the mostly performed collaboration form. Coconstruction comes in second and division of work is least performed. The mean values of the latter two differ more than 1.01 to exchange and 0.13 between each other.

With this outcome, the hypothesis, that the students mostly perform exchange as collaboration form, can be confirmed.

Table 3: Performed types of collaboration

\begin{tabular}{|l|l|l|l|}
\hline Collaboration type & $\mathbf{n}$ & M & SD \\
\hline Exchange & 301 & 3.34 & 0.73 \\
\hline Division of Work & 300 & 2.20 & 0.77 \\
\hline Co-construction & 299 & 2.33 & 0.77 \\
\hline
\end{tabular}

Table 4: Correlation of the three collaboration types

\begin{tabular}{|l|l|l|l|}
\hline \multicolumn{2}{|c|}{} & Exchange & Division of work \\
\hline \multirow{4}{*}{ Exchange } & Pearson corr. & & .526 \\
\cline { 2 - 4 } & $\boldsymbol{p}$ & & 0.000 \\
\hline \multirow{3}{*}{ Co-construction } & $\boldsymbol{n}$ & & 300 \\
\hline & Pearson corr. & .612 & .699 \\
\cline { 2 - 4 } & $\boldsymbol{p}$ & 0.000 & 0.000 \\
\cline { 2 - 4 } & $\boldsymbol{N}$ & 299 & 299 \\
\hline
\end{tabular}

\subsubsection{Collaboration partners}

The results are based on the same scale as described in the previous chapter.

An important outcome is that students mostly collaborate with their mentors. Translating the numbers back into the scales, a mean of $3.16(\mathrm{SD}=0.9)$ implies that they averagely collaborated more than '1-2 times per month' (3) with their mentors and less than '1-2 times per week' (4). The mean values of the 'fellow students' group and the 'other teachers' group 
signifies a collaboration frequency of 1-2 times per month (3) and less (2) with both collaboration partner groups.

The results of the correlation calculation show, that all differences between the collaboration partner groups are significant. The differences between undertaking collaboration with mentors and fellow students have a moderate effect size and the other two comparisons (mentors - other teachers and mentors - fellow students) low effect sizes. That means, that the more students collaborate with one group, the more they also collaborate with another. The hypothesis 'The more students collaborate with one group of partners, the less they collaborate with the other two groups' cannot be verified. Moreover, a change of the hypothesis as follows is adequate: The more a student collaborates with one group, the more likely he/she will also collaborate with partners from the other two groups.

Table 5: Performed collaboration with partner groups

\begin{tabular}{|l|l|l|l|}
\hline Partner group & n & M & SD \\
\hline fellow students & 298 & 2.19 & 0.74 \\
\hline mentors & 301 & 3.16 & 0.90 \\
\hline other teachers & 298 & 2.50 & 0.97 \\
\hline
\end{tabular}

Table 6: Correlation between the collaboration performances of students with mentors, fellow students and other teachers

\begin{tabular}{|l|l|l|l|l|}
\hline \multicolumn{2}{|l|}{} & & other teachers & fellow students \\
\hline \multirow{3}{*}{ mentors } & Pearson corr. & & .296 & .435 \\
\cline { 2 - 5 } & $\boldsymbol{p}$ & & 0.00 & 0.00 \\
\cline { 2 - 5 } fellow students & $\boldsymbol{n}$ & & 298 & 298 \\
\hline & $\boldsymbol{p}$ & & .207 & \\
\cline { 2 - 5 } & $\boldsymbol{n}$ & & 0.00 & \\
\hline
\end{tabular}

\section{Analysis}

The hypotheses for the quantitative study were based on previous studies on teachers and teaching students as well as the qualitative study that led to the survey. Three out of four hypothesis could not or only partly be confirmed based on the findings. 
Previous studies with fully trained teachers showed that there is more collaboration between teachers in primary schools than in secondary schools (Bauer, 2008, p. 850; Steinert et al., 2006). This study shows that the differences are already visible in teacher training. The students for primary school teaching had all in all higher values in rating, intention and performance in comparison to prospective secondary teachers. Yet only the data of intention was significantly different between the two groups.

Regarding the gap between rating, intention and performance, the results also confirmed previous study findings as there was no correlation between rating and performance. Nevertheless, we could find correlations between rating and intention with a medium effect size. The higher students rate collaboration actions, the more they intent to perform it. However, they do not act accordingly in their internship and even the correlation between intention and performance has a small effect. This finding can also be seen in former studies on teachers (Pröbstel \& Soltau, 2012, p. 64; Terhart \& Klieme, 2006, pp. 163-164). There are several theoretical and researched constructs on how in particular the gap between rating and performance arises, but they mostly focus on trained teachers and not on students in teacher training (Bondorf, 2013; Pröbstel \& Soltau, 2012). Therefore, further research with this specific group is necessary.

Exchange is the most performed type of collaboration on a monthly to weekly basis. This hypothesis is not only based on studies with teachers but also on the previous interview study. In contrast to results from studies with fully trained teachers, co-construction takes the second place and division of work the third. Other studies showed that usually division is ranked second most and co-construction is used least (Richter \& Pant, 2016, p. 21).

\section{Conclusion}

The results of the students group in many ways match with the findings from studies with trained teachers. We can see general tendencies and similarities between education students and teachers. This means that opinions and habits of teacher collaboration might not only be formed during the actual job, but earlier. However, the students seem more willing to collaborate as there are less and smaller gaps between the different school forms and the student's approaches towards collaboration. These results support the idea, that the improvement and increased usage of collaborative actions in teacher education might lead to a change in the job-based performance in school in the long run. 
The internship might offer a chance to enhance co-construction because of its structure: the interns always have to accompany another teacher and can teach in the respective class. This could be a key structure to increase co-constructional actions as team teaching or the collective planning of lessons.

\subsection{Discussion and research limitation}

This study consists only of a small sample compared to students undergoing teacher training. To get a better impression of how the situation is nation- and worldwide, more studies need to follow. As the teacher training is very diverse not only between countries but even in Germany and other countries itself, it is almost impossible to proclaim general advises on what and how to change. However, the different systems can and should learn from each other and never stop seeking improvement.

The practical semester in Germany is a new approach to a more practice-oriented teacher training. Still it is undergoing changes and new approaches for improvement. The implementation of this 6-month internship opened a new field of research and a lot of studies investigate the effects and outcomes of it (König \& Rothland, 2018; Rothland \& Straub, 2018). The research on collaboration within this internship is a new approach of research. However, the here presented cross-section study shows only two semesters of internships. One could state that the practical semester is not yet sufficiently implemented in the teacher education system and therefore long-term effects could evolve. It is not yet visible whether the investigated forms and intensity of collaboration might change automatically over time. Long-term studies could find out whether the interactions between teachers and interns changes over time, when participants (teachers, university staff, pupils) of the practical semester accept it more and more as a routine in schools.

The here shown results must be further examined and a qualitative study will follow to explain and question the quantitative data, as explained in the following chapter.

As mentioned earlier, there are other studies investigating the effect of the vocationalisation of the university education (Houston et al., 2016). Teacher training should not see itself separated from other academic training and learn from the outcomes of these studies. If other students profit from internships and practical learning, so might teacher students do. Many studies investigate how collaborative settings enhance students' performance (Aleksić \& Arula, 2017) and teachers are responsible to create these environments. There are also studies regarding other fields of work apart from the schooling section with a closer look on how collaboration 
influences work related environments (Bikard, Murray, \& Gans, 2015). This shows that not only the educational believes in the advantages of collaboration but also other companies and industries.

\subsection{Future research}

With a following interview study, the mixed methods design will be extended to a multiphase sequential design. The study will be led by the question how students experience collaboration situations during their practical semester in order to find out why they collaborate in the way they do or do not do. The leading question will be focused on the emergence of the gap between rating and intention and performance. Also, the study explores why they collaborate mostly with mentors and how the already performed actions with the different collaboration partners start and continue.

The overall objective is to find out how the university can implement collaborative habits during the theoretical training and internships. The results so far are very informative but lead to further questions. Future research can find specific differences between students in teacher training and fully trained teachers. Furthermore, the internship might need to be adapted towards focussing on the students' specific needs.

\section{References}

Avalos, B. (2011). Teacher professional development in Teaching and Teacher Education over ten years. Teaching and Teacher Education, 27(1), 10-20. https://doi.org/10.1016/j.tate.2010.08.007

Bauer, K.-O. (2008). Lehrerinteraktion und-kooperation. In W. Helsper \& J. Böhme (Eds.), Handbuch der Schulforschung (2nd ed., pp. 839-856). Wiesbaden: VS Verlag für Sozialwissenschaften / GWV Fachverlage GmbH, Wiesbaden. https://doi.org/10.1007/978-3-531-91095-6 34

Bondorf, N. (2013). Profession und Kooperation: Eine Verhältnisbestimmung am Beispiel der Lehrerkooperation. Zugl.: Mainz, Univ., Diss., 2011. Wiesbaden: Springer VS.

Cherechi, I. H. (2018). The Challenges of Teacher Education in the 21 st Century Nigeria. PEOPLE: International Journal of Social Sciences, 4(1), 716-727. https://doi.org/10.20319/pijss.2018.41.716727

Goddard, Y. L., Goddard, R. D., \& Tschannen-Moran, M. (2007). A Theoretical and Empirical Investigation of Teacher Collaboration for School Improvement and Student 
Achievement in Public Elementary Schools. Teachers College Record, 109(4), 877-896. Retrieved May 07, 2018.

Gräsel, C., Fußangel, K., \& Pröbstel, C. (2006). Lehrkräfte zur Kooperation anregen: Eine Aufgabe für Sisyphos? Zeitschrift für Pädagogik, 52(2), 205-219.

Gräsel, C., \& Gruber, H. (2000). Kooperatives Lernen in der Schule: Theoretische Ansätze Empirische Befunde - Desiderate für die Lehramtsausbildung. In N. Seibert (Ed.), Perspektive Schulpädagogik. Unterrichtsmethoden kontrovers (1st ed.). Bad Heilbrunn/Obb.: Klinkhardt.

Houston, M., Krüger, K., Molas, A., Osborne, M., \& Jiménez, L. (2016). Cooperation in workoriented learning in higher education. PEOPLE: International Journal of Social Sciences, 2(1), 685-705. https://doi.org/10.20319/pijss.2016.s21.685705

Kuper, H., \& Kapelle, N. (2012). Lehrerkooperation aus organisationssoziologischer sicht. In E. Baum, T.-S. Idel, \& H. Ullrich (Eds.), SpringerLink Bücher. Kollegialität und Kooperation in der Schule. Theoretische Konzepte und empirische Befunde (pp. 41-51). Wiesbaden: VS Verlag für Sozialwissenschaften. https://doi.org/10.1007/978-3-53194284-1_3

Little, J. W. (1990). The persistence of privacy: Autonomy and initiative in teachers' professional relations. Teachers College Record, 91(4), 509-536. Retrieved May 08, 2018.

Meddour, M. (2017). I Am Not Ready For Teaching! Efl Graduates’ Challenges And Expectations Of The Profession. PEOPLE: International Journal of Social Sciences, 3(3), 759-777. https://doi.org/10.20319/pijss.2017.33.759777

Pröbstel, C., \& Soltau, A. (2012). Wieso Lehrkräfte (nicht) kooperieren - Die Bedeutung „,personaler Faktoren“ in der Zusammenarbeit am Arbeitsplatz Schule. In E. Baum, T.-S. Idel, \& H. Ullrich (Eds.), SpringerLink Bücher. Kollegialität und Kooperation in der Schule. Theoretische Konzepte und empirische Befunde (pp. 55-76). Wiesbaden: VS Verlag für Sozialwissenschaften.

Richter, D., \& Pant, H. A. (2016). Lehrerkooperation in Deutschland: Eine Studie zu kooperativen Arbeitsbeziehungen bei Lehrkräften der Sekundarstufe I. Gütersloh: Bertelsmann Stiftung. 
Ronfeld, Matthew, Owens Farmer, S., McQueen, K., \& Grissom, J. A. (2015). Teacher collaboration in instructional teams and student achievement. American Educational Research, 52(3), 475-514. https://doi.org/10.3102/0002831215585562

Rothland, M. (2012). Lehrerbildung und Lehrerkooperation: Programmatik, Ausbildungsrealität und Befunde zu den Voraussetzungen von Lehramtsstudierenden für die kollegiale Zusammenarbeit im Beruf. In E. Baum, T.-S. Idel, \& H. Ullrich (Eds.), SpringerLink Bücher. Kollegialität und Kooperation in der Schule. Theoretische Konzepte und empirische Befunde (pp. 191-204). Wiesbaden: VS Verlag für Sozialwissenschaften. https://doi.org/10.1007/978-3-531-94284-1_13

Schaarschmidt, U. (Ed.) (2005). Halbtagsjobber?: Psychische Gesundheit im Lehrerberuf Analyse eines veränderungsbedürftigen Zustandes (2. Auflage, Druck nach Typoskript). Weinheim, Basel: Beltz Verlag.

Schüssler, R., Schwier, V., Klewin, Gabriele, Schicht, Saskia, Schöning, A., \& Weyland, U. (Eds.) (2014). UTB Schulpädagogik: Vol. 4168. Das Praxissemester im Lehramtsstudium: Forschen, Unterrichten, Reflektieren. Bad Heilbrunn: Klinkhardt. Soltau, A. Zusammenarbeit in Schulkollegien: Teamorientierung und Einstellungen zu Formen der Lehrerkooperation bei Bremer Lehrkräften. Diplomarbeit, from Universität Bremen: http://elib.suub.uni-bremen.de/dipl/docs/00000080.pdf.

Steinert, B., Klieme, E., Maag Merki, K., Döbrich, P., Halbheer, U., \& Kunz, A. (2006). Lehrerkooperation in der Schule: Konzeption, Erfassung, Ergebnisse. Zeitschrift für Pädagogik, 52(2), 185-204.

Terhart, E. (2002). Standards für die Lehrerbildung: Eine Expertise für die Kultusministerkonferenz. Zfl-Text: Vol. 24. Münster: Inst. für Schulpädag. und Allgemeine Didaktik Univ. Münster.

Vangrieken, K., Dochy, F., Raes, E., \& Kyndt, E. (2015). Teacher collaboration: A systematic review. Educational Research Review, 15, 17-40. https://doi.org/10.1016/j.edurev.2015.04.002

Werner, S. (2012). Wie kommt Kooperation in die Schule?: Zum Spannungsverhältnis zwischen Interventionsidee und schulpraktischer Umsetzung. In E. Baum, T.-S. Idel, \& H. Ullrich (Eds.), SpringerLink Bücher. Kollegialität und Kooperation in der Schule. Theoretische Konzepte und empirische Befunde (pp. 135-148). Wiesbaden: VS Verlag für Sozialwissenschaften. https://doi.org/10.1007/978-3-531-94284-1_9 